\title{
HUBUNGAN TINGKAT PENGETAHUAN ORANG TUA DENGAN STATUS KEBERSIHAN GIGI DAN MULUT ANAK TUNA RUNGU USIA 9-12 TAHUN DI SLB KOTA PADANG
}

\author{
Chindy Septia Ningsih ${ }^{1}$ dan Didin Kustantiningtyastuti ${ }^{2}$ \\ ${ }^{1}$ Fakultas Kedokteran Gigi Universitas Andalas, Padang, Sumatera Barat, Indonesia \\ ${ }^{2}$ Departemen Public Health, Fakultas Kedokteran Gigi, Universitas Andalas, Padang, Sumatera Barat, \\ Indonesia
}

\begin{abstract}
Parents' knowledge is very important in keeping children's mouth and teeth clean especially on disability children. According to the researcher's survey, it hasn't been conducted a research yet about oral hygiene indeks of deaf children. The objective of this research is to determine the correlation of parents' knowledge with oral hygiene indeks of 9-12 years old deaf children at extraordinary schools in Padang”.

The design of this research is observational analytic with cross sectional approach. Population of this research is all deaf children at 5 extraordinary schools who are the most ages are 9-12 years old. They are 34 children whom are selected by using total sampling technique. Time of the research is in March 2016. The research instruments are questionnaire and oral hygiene status. Univariate analysis is shown in the form of frequency distribution tables and bivariate analysis is by using chi-square test with 95\% $\alpha=0.05$ level of trust.

Research findings showed more than a half $(73,5 \%)$ children had not good level of mouth and teeth clean; only a small percentage (20,6\%) parents had high knowledge; and there was no significant correlation between parents' knowledge and oral hygiene indeks simplifield (OHI-S) of 9-12 years old deaf children at extraordinary. PValue $=0.187$.
\end{abstract}

Keywords : Parents' knowledge, oral hygiene indeks of deaf children

Affiliasi penulis: Fakultas Kedokteran Gigi, Universitas Andalas, Padang, Sumatera Barat, Indonesia

Korespondensi: Audia Tria Putri e-mail: indydofa@gmailcom

\section{PENDAHULUAN}

Pengetahuan merupakan domain yang penting untuk terbentuknya tindakan seseorang. Pengetahuan dapat diperoleh secara alami maupun secara terencana melalui pendidikan. Pengetahuan dapat dipengaruhi oleh berbagai faktor seperti tingkat pendidikan, ekonomi, sosial, lingkungan dan kehadiran sarana pelayanan. Tingkat pengetahuan menggambarkan tingkat kemampuan seseorang dalam memperoleh dan memahami informasi kesehatan. ${ }^{1}$

Pengetahuan orang tua sangat penting dalam menjaga kebersihan gigi dan mulut anak, apalagi pada anak yang memiliki kebutuhan khusus. Orang tua berperan sebagai orang terdekat dari anak yang senantiasa mendidik, melatih dan memberikan kasih sayang kepada anak. Menurut Sayuti (2010), kebersihan mulut sangat ditentukan oleh perilaku. Perilaku orang tua sangat penting dalam terbentuknya perilaku yang mendukung atau tidak mendukung anak dalam menjaga kebersihan gigi dan mulut., ${ }^{2,3}$ 
Faktor lain seperti sosial ekonomi juga mempengaruhi kesehatan gigi dan mulut anak. Status sosial ekonomi keluarga dilihat dari pekerjan dan pendapatan orang tua. Status kesehatan rongga mulut yang buruk lebih tinggi pada anak yang berasal dari kalangan sosial ekomi rendah. Hal ini disebabkan kemampuan orang tua dalam memenuhi kebutuhan gizi anak. Anak sering mengkonsumsi makanan yang bersifat kariogenik. Rendahnya pengetahuan akan kesehatan gigi dapat dilihat dari kesehatan mulut yang buruk, karies tinggi pada keluarga, jarang melakukan kunjungan ke dokter gigi sehingga banyak karies gigi yang tidak dirawat. ${ }^{4-6}$

Kesehatan gigi dan mulut merupakan hal yang perlu mendapatkan perhatian khusus. Berdasarkan data World Health Organization (WHO) tahun 2012, di seluruh dunia 60-90\% anak-anak sekolah memiliki karies yang sering menimbulkan rasa sakit serta mempengaruhi kualitas hidup. Berdasarkan data Riset Kesehatan Dasar Tahun 2007, prevalensi karies pada anak umur 1-4 tahun di Indonesia sebesar $6,9 \%$, sedangkan pada anak umur 5-9 tahun sebesar 21,6 \%. Di Provinsi Sumatera Barat penduduk dengan umur 14 tahun yang mempunyai masalah dengan kesehatan gigi dan mulut sebesar 5,2\% dan pada usia 5-9 tahun sebesar 21,1\%, dari angka ini terlihat dengan meningkatnya umur meningkat juga masalah kesehatan gigi dan mulutnya, terutama karies. ${ }^{7}$

Kesehatan gigi dan mulut merupakan hal yang perlu mendapat perhatian khusus dari tenaga kesehatan baik dokter gigi maupun perawat gigi. Salah satu indikator kesehatan gigi dan mulut adalah tingkat kebersihan gigi dan mulut. Adanya sisa makanan dan kalkulus pada permukaan gigi yang diukur dengan indeks Oral Hygiene Index Simplified dari Green and Vermillion. ${ }^{2,8,9}$ Status kebersihan gigi dan mulut (OHI-S) merupakan jumlah indeks debris $(D I)$ dan indeks kalkulus $(C I)$. Indeks $O H I-S$ diukur dengan melihat skor pada 6 buah gigi permanen sebagai gigi indeks. Indeks $O H I-S$ berguna untuk melihat kebersihan rongga mulut apakah masuk dalam kategori baik, sedang, maupun buruk. ${ }^{10,11}$

Menurut Undang-Undang Republik Indonesia Nomor 4 tahun 1997 pasal 1 tentang penyandang cacat, anak penyandang cacat adalah setiap anak yang mempunyai kelainan fisik dan/ atau mental, yang dapat mengganggu merupakan rintangan dan hambatan baginya untuk melakukan kegiatan secara selayaknya. Hak tersebut diperjelas dalam Undang-Undang Nomor 23 tahun 2002 
tentang Perlindungan Anak, yang menegaskan bahwa semua anak termasuk anak cacat mempunyai hak untuk kelangsungan hidup, tumbuh dan berkembang, dan mendapatkan fasilitas kesehatan. Salah satu kelompok penyandang cacat adalah tuna rungu. Anak tuna rungu adalah anak yang mengalami gangguan pada indera pendengarannya sehingga mengakibatkan ketidakmampuan mendengar dan biasanya memiliki hambatan dalam berbicara sehingga mereka disebut juga tunawicara. ${ }^{7,12}$

Berdasarkan data Sensus Nasional Biro Statistik (BPS) tahun 2007 jumlah penyandang cacat di Indonesia sebesar 0,7\% dari jumlah penduduk sebesar 211.428.572 atau sebanyak 1.480 .000 jiwa. Sebagian dari jumlah tersebut $24,45 \%$ atau 361.860 diantaranya adalah anak-anak usia 0-18 tahun dan 21,42\% atau 317.016 anak merupakan anak usia sekolah (5-18 tahun). Sekitar 66.610 anak usia sekolah penyandang cacat $(14,4 \%$ dari seluruh anak penyandang cacat) ini terdaftar di Sekolah Luar Biasa (Kemenkes, 2010). Persentase penyandang cacat di Provinsi Sumatera Barat sekitar 2,7 \% (Susenas, 2012).

Menurut organisasi kesehatan dunia (WHO), lebih dari 5\% dari populasi dunia, sekitar 360 juta orang mengalami gangguan pendengaran (328 juta orang dewasa dan 32 juta anak-anak). Prevalensi anak tuna rungu di Indonesia berdasarkan data statistik Depertemen Pendidikan Nasional Indonesia menunjukkan bahwa jumlah anak-anak tuna rungu di Indonesia cukup tinggi mencapai $0,17 \%$ dimana 17 dari 10.000 anak pra sekolah sampai umur 12 tahun mengalami tuli. Jumlah penyandang tuna rungu di Provinsi Sumatera Barat jumlah sekitar 12.250 jiwa. $^{13,14}$

Kesehatan gigi pada anak tuna rungu usia sekolah memang buruk dibanding dengan anak normal usia sekolah. $^{15}$ Ini disebabkan mereka memiliki kekurangan dan keterbatasan mental maupun fisik untuk melakukan pembersihan gigi sendiri secara optimal. $^{14,16}$ Penelitian yang dilakukan Nurisa pada anak tuna rungu usia sekolah di Yogyakarta tahun 2011 yang dikutip Mintjelungan, dkk menunjukkan bahwa status kebersihan gigi pada anak tuna rungu buruk disebabkan kebersihan mulut yang kurang diperhatikan karena keterbatasan kemampuan dalam menjaga kebersihan gigi. Menurut Wiyakusuma yang dikutip Dewi 2004, anak-anak dan remaja adalah kelompok yang paling rentan terjadinya karies gigi terutama penderita cacat, beberapa penelitian menyebutkan bahwa penderita cacat 
mempunyai kesehatan mulut yang buruk dari pada penderita normal. Menurut Noerdin tahun 1996, penderita cacat mempunyai keterbatasan untuk melaksanakan prosedur membersihkan mulut.

Berdasarkan data Dinas Pendidikan Provinsi Sumatera Barat, terdapat 36 Sekolah Luar Biasa (SLB) Kota Padang dengan 2 SLB milik pemerintah dan 34 milik swasta. Menurut survey peneliti belum pernah dilakukan penelitian mengenai kebersihan gigi dan mulut pada anak tuna rungu. Oleh sebab itu, penulis tertarik melakukan penelitian mengenai "Hubungan Tingkat Pengetahuan Orang Tua Dengan Status Kebersihan Gigi Dan Mulut Anak Tuna Rungu Usia 9-12 Tahun di SLB Kota Padang."

\section{METODE PENELITIAN}

Penelitian ini merupakan jenis penelitian observasional analitik dengan menggunakan pendekatan desain cross sectional study untuk menganalisis hubungan tingkat pengetahuan orang tua dengan status kebersihan gigi dan mulut anak tuna rungu usia 9-12 tahun di SLB Kota Padang. Penelitian akan dilakukan pada bulan Februari 2016 dan Maret 2016 di 5 SLB Kota Padang dengan jumlah murid terbanyak.
Pengambilan sampel pada penelitian ini adalah secara total sampling yaitu suatu pengambilan sampel yang dilakukan dengan cara memakai seluruh anggota dijadikan sampel dalam penelitian. Hasil dari survey didapatkan sampel sebanyak 34 orang anak tuna rungu yang berada di 5 SLB yang terbanyak muridnya di Kota Padang yaitu 16 siswa di SLB Wacana Asih, 5 Siswa di SLB YPAC Sumbar, 8 siswa YPPLB, 2 siswa di SLB Luki, 3 siswa di SLB Alhidayah.

Pada penelitian ini, peneliti mengumpulkan data dengan menggunakan kuisioner. Kuisioner merupakan suatu teknik atau cara pengumpulan data secara tidak langsung. Jenis kuisioner yang digunakan adalah kuisioner dengan jawaban tertutup yaitu kuisioner yang alternativ jawabannya sudah disediakan oleh peneliti. Dalam kuisioner berisi daftar pertanyaan yang harus diisi oleh responden. Kuisioner diukur untuk mengetahui tingkat pengetahuan orang tua terhadap status kebersihan gigi dan mulut anak tuna rungu usia 9-12 tahun.

Kuisioner ini terdiri dari dua bagian, yaitu karakteristik responden dan pengetahuan responden mengenai kebersihan gigi dan mulut anak tuna rungu usia 9-12 tahun. Karakteristik 
responden yang diteliti meliputi jenis kelamin, usia, pekerjaan, dan pendidikan terakhir. Sedangkan kuisioner pengetahuan responden berisi 20 pertanyaan yang disertai alternativ jawaban yang benar dan salah. Setiap pertanyaan mendapat nilai 1 untuk jawaban yang benar dan nilai 0 untuk jawaban yang salah. Penelitian dilakukan dengan cara membandingkan jumlah skor jawaban yang didapat dengan skor yang diharapkan (tertinggi) kemudian dikalikan $100 \%$ dan hasilnya berupa persentase. Rumus yang digunakan sebagai berikut :

$$
\begin{aligned}
& \mathrm{N} \\
& \mathrm{Sm}
\end{aligned}=\mathrm{Sp} \times 100 \%
$$

Keterangan :

$\mathrm{N}=$ nilai pengetahuan

$\mathrm{Sp}=$ skor yang di dapat

$\mathrm{Sm}=$ skor tertinggi maksimum

Selanjutnya, seluruh nilai dijumlahkan skornya, jika skor $>80 \%$ tingkat pengetahuannya dikategorikan tinggi, jika total skor antara $60-80 \%$ tingkat pengetahuannya dikategorikan sedang, dan jika total skor $<60 \%$ tingkat pengetahuan dikategorikan rendah.

\section{HASIL PENELITIAN}

Pengumpulan data dilakukan pada anak tuna rungu usia 9-12 tahun di SLB Kota Padang tanggal 10 Maret - 18
Maret. Sampel pada penelitian ini berjumlah 34 orang. Pengambilan data dilakukan dengan menggunakan kuisioner tingkat pengetahuan dan pengukuran kebersihan gigi dan mulut dengan OHI-S.

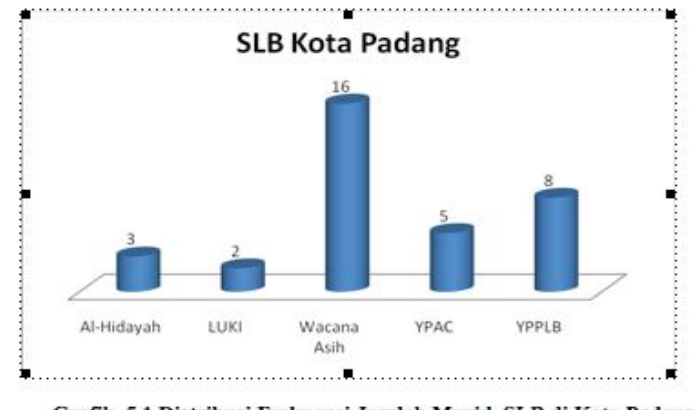

Grafik 5.1 Distribusi Frekuensi Jumlah Murid SLB di Kota Padang

5.2 Karateristik Responden

Tabel 5.1 Distribusi Frekuensi Karakteristik Orang Tua Pada Anak Tuna

\begin{tabular}{|c|c|c|}
\hline Karakteristik 0rang Tua & $F$ & $\%$ \\
\hline \multicolumn{3}{|l|}{ Umur: } \\
\hline - Dewasa awal & 31 & 91,2 \\
\hline - Dewasa akhir & 3 & 8,8 \\
\hline Total & 34 & 100 \\
\hline \multicolumn{3}{|l|}{ Jenis Kelamin : } \\
\hline - Laki-Laki & 11 & 32,4 \\
\hline - Perempuan & 23 & 67,6 \\
\hline Total & 34 & 100 \\
\hline \multicolumn{3}{|l|}{ Pendidikan : } \\
\hline - SMP & 5 & 14,7 \\
\hline - SMA & 26 & 76,5 \\
\hline - D3 & 1 & 2,9 \\
\hline - $\mathrm{SI}$ & 2 & 5,9 \\
\hline Total & 34 & 100 \\
\hline
\end{tabular}
rungu Usia 9-12 Tahun Di SLB Kota Padang

Berdasarkan tabel 5.1 diperoleh hasil sebagian besar $(91,2 \%)$ umur responden adalah pada dewasa awal $(91,2 \%)$, lebih dari separuh $(67,6 \%)$ responden dengan jenis kelamin perempuan dan sebagian besar $(76,5 \%)$ responden memiliki pendidikan SMA pada orang tua anak tuna rungu usia 9-12 tahun di SLB Kota Padang. 
Berdasarkan grafik diatas diperoleh SLB tempat penelitian paling banyak pada SLB Wacana Asih sebanyak 16 anak, SLB YPPLB 8 anak, SLB YPAC 5 anak, SLB Al-Hidayah 3 anak dan paling sedikit SLB LUKI sebanyak 2 anak.

\section{Analisa Univariat}

Tabel 5.2 Distribusi Erekuensi_Kebersihan Gigi dan Mulut (OHI-S) Pada Anak Tuna Rungu Usia 9-12 Tahun di SLB Kota Padang

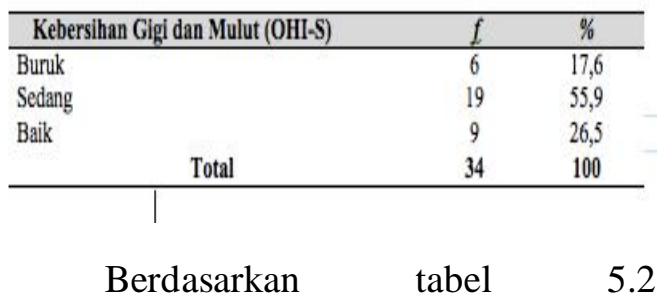

menunjukkan bahwa lebih dari separuh $(55,9 \%)$ anak memiliki kebersihan gigi dan mulut pada kategori sedang pada anak tuna rungu di SLB Kota Padang.

\section{Tabel 5.3 Distribusi Frekuensi. Tingkat Pengetahuan 0rang Tua Pada Anak Tuna Rungu Usia 9-12 Tahun di SLB Kota Padang}

\begin{tabular}{lccc}
\hline \multicolumn{2}{c}{ Tingkat Pengetahuan Orang Tua } & $f$ & $\%$ \\
\hline Rendah & 12 & 35,3 \\
Sedang & 15 & 44,1 \\
Tinggi & Total & 7 & 20,6 \\
& \multirow{2}{*}{ Berdasarkan } & tabel & 5.3
\end{tabular}

menunjukkan hanya sebagian kecil $(20,6 \%)$ orang tua memiliki tingkat pengetahuan tinggi tentang kebersihan gigi dan mulut pada anak tuna rungu usia 9-12 tahun di SLB Kota Padang.

\section{Analisa Bivariat}

Tabel 5.4 Hubungan Tingkat Pengetabuan Orang Tua Dengan Status Kebersihan Gigi Dan Mulut Anak Tuna Rungu Usia 9-12 Tahun Di SLB Kota Padang

\begin{tabular}{lcccccccc}
\hline & \multicolumn{9}{l}{ Kebersihan Gigi dan Mulut (OHI $S$ ) } & \multirow{2}{*}{ Total } \\
\cline { 2 - 7 } $\begin{array}{c}\text { Tingkat } \\
\text { Pengetahuan }\end{array}$ & Buruk & \multicolumn{3}{c}{ Sedang } & \multicolumn{2}{c}{ Baik } & & \\
\cline { 2 - 8 } & $f$ & $\%$ & $f$ & $\%$ & $f$ & $\%$ & $f$ & $\%$ \\
\hline Rendah & 6 & 50 & 5 & 41,7 & 1 & 8,3 & 12 & 100 \\
Sedang & 0 & 0 & 10 & 66,7 & 5 & 33,3 & 15 & 100 \\
Tinggi & 0 & 0 & 4 & 57,1 & 3 & 42,9 & 7 & 100 \\
\hline Total & 6 & 17,6 & 19 & 55,9 & 9 & 26,5 & 34 & 100
\end{tabular}

Pada tabel diatas karena ada cell yang kosong, jadi peneliti membuat kategori OHI-S yaitu kurang baik dan baik dengan uraian sebagai berikut:

Tabel 5.5 Hubungan Tingkat Pengetahuan Orang Tua Dengan Status Kebersihan Gigi Dan Mulut Anak Tuna Rungu Usia 9-12 Tahun Di SLB Kota Padang Berdasarkan Kategori Kurang Baik dan Baik

\begin{tabular}{|c|c|c|c|c|c|c|}
\hline \multirow{3}{*}{$\begin{array}{c}\text { Tingkat } \\
\text { Pengetahuan }\end{array}$} & \multicolumn{3}{|c|}{$\begin{array}{c}\text { Kebersihan Gigi dan Mulut } \\
\text { (0HI-S) }\end{array}$} & \multirow{2}{*}{\multicolumn{2}{|c|}{ Total }} & \multirow{3}{*}{ PValue } \\
\hline & Kurang Baik & \multicolumn{2}{|c|}{ Baik } & & & \\
\hline & $f$ & J & $\%$ & $f$ & $\%$ & \\
\hline Rendah & 91,7 & I & 8,3 & 12 & 100 & \\
\hline Sedang & 66,7 & 5 & 33,3 & 15 & 100 & 1 \\
\hline Tinggi & 57,1 & 3 & 42,9 & 7 & 100 & $0,10 /$ \\
\hline Total & 73,5 & 9 & 26,5 & 34 & 100 & \\
\hline
\end{tabular}

Berdasarkan tabel 5.5 diperoleh hasil kebersihan gigi dan mulut kurang baik lebih banyak pada tingkat pengetahuan orang tua yang rendah $(91,7 \%)$ dibandingkan dengan tingkat pengetahuan sedang $(66,7 \%)$ dan tinggi $(57,1 \%)$.

Hasil uji statistik (chi square) diperoleh nilai $\mathrm{p}=0,187>0,05$, maka dapat disimpulkan bahwa tidak terdapat hubungan yang bermakna antara tingkat 
pengetahuan orang tua dengan kebersihan gigi dan mulut pada anak tuna rungu usia 9-12 tahun di SLB Kota Padang, mungkin ada faktor lain yang mempengaruhi OHIS seperti kepedulian, tingkat ekonomi, sikap, dan tindakan orang tua terhadap kebersihan gigi dan mulut anak tuna rungu.

\section{PEMBAHASAN}

Penelitian ini dilakukan pada siswa SLB Kota Padang sebanyak 34 orang, diperoleh distribusi umur dari anak tuna rungu yaitu umur siswa SLB paling banyak yaitu 9 tahun sebanyak 15 anak, umur 11 tahun sebanyak 8 anak, umur umur 10 tahun sebanyak 6 anak dan umur 12 tahun sebanyak 5 anak. Pada responden juga diperoleh distribusi umur sebagian besar $(91,2 \%)$ umur responden adalah pada dewasa awal $(91,2 \%)$ dan dewasa akhir $8,8 \%$.

Dari hasil penelitian, diperoleh tingkat pengetahuan orang tua mengenai kebersihan gigi dan mulut yang memiliki pengetahuan dengan kategori tinggi 7 responden (20,6\%), kategori sedang 15 responden $(44,1 \%)$, dan kategori rendah 12 responden $(35,3 \%)$. Jadi bisa disimpulkan bahwa hanya sebagian kecil responden $(20,6 \%)$ yang memiliki pengetahuan yang tinggi. Tingkat pengetahuan responden dinilai berdasarkan jawaban benar dan salah dalam kuisioner.

Tingkat pengetahuan responden dinilai berdasarkan jawaban benar dan salah dalam kuisioner. Dari 23 pernyataan yang ada, terdapat jawaban yang salah lebih dari $50 \%$ sebanyak 4 pernyataan yaitu pada pernyataan nomor 10, 13, 15 dan 23. Pernyataan nomor 10 responden yang menjawab salah sebanyak 50\%, ini disebabkan karena responden tidak tahu bahwa ada kandungan fluoride pada pasta gigi, sehingga responden menjawab tidak perlu menggunakan pasta gigi yang mengandung fluoride. Menurut Budhiharto (2008), pasta gigi yang mengandung fluoride dan agen antimicrobial lainnya seperti triclosan memberikan manfaat dalam mengontrol karies dan gingivitis.

Sebanyak $50 \%$ responden menjawab salah pada pernyataan nomor 13 karena responden tidak tahu pemeriksaan gigi anak berkebutuhan khusus setiap 2-3 bulan sekali. Ini berbeda dengan pemeriksaan gigi 1 kali 6 bulan pada anak normal, hal ini disebabkan penderita cacat memerlukan perhatian khusus secara terus menerus disebabkan mempunyai keterbatasan untuk melaksanakan prosedur membersihkan mulutnya dan membutuhkan bantuan dari orang lain (Ami Anggela, 2005). Selain 
itu prosedur perawatan gigi anak cacat lebih sulit sehingga diperlukan komunikasi dan kerja sama yang baik antara dokter gigi, orang tua, dan anak sendiri (PIH Unair).

Menurut Wijayakusuma yang dikutip Dewi 2004, anak-anak dan remaja adalah kelompok yang rentan terjadinya karies gigi terutama penderita cacat. Anak yang cacat memiliki resiko yang lebih tinggi akan masalah kesehatan gigi dan mulut karena mereka memiliki kekurangan dan keterbatasan fisik dan mental untuk melakukan pembersihan gigi sendiri secara optimal. Salah satu penderita cacat yaitu tuna rungu. Tuna rungu adalah suatu kelainan fisik yang berhubungan dengan berkurangnya pendengaran yang menghambat perkembangan bicara dan bahasanya (Parmanarian, 1995). Hal ini dapat menimbulkan hambatan di dalam penilaian maupun pemeliharan kebersihan rongga mulut. Beberapa penelitian pun mengatakan hambatan dalam berbicara anak tuna rungu menyebabkan kurangnya lidah dalam berperan membangun vocal sehingga memperparah maloklusi. Anak tuna rungu memiliki persentase kerusakan gigi yang tinggi serta kebersihan gigi yang rendah. Secara umum hal ini disebabkan oleh keterbatasan fisik mereka, perawatan kesehatan gigi yang tidak efektif, kurang kooperaif dan kurangnya akses untuk perawatan gigi yang baik (Oranbudid, dkk, 2009). Masalah yang sering ditemukan pada gigi dan mulut anak tuna rungu seperti status kebersihan gigi dan mulut buruk, hilangnya gigi karena karies, crowding (gigi berjejal).

Pengetahuan orang tua sangat penting dalam menjaga kebersihan gigi dan mulut anak. Orang tua berperan sebagai orang terdekat dari anak yang senantiasa mendidik, melatih dan memberikan kasih sayang kepada anak. Pengetahuan orang tua sangat penting dalam menjaga kebersihan gigi dan mulut anak, apalagi pada anak yang memiliki kebutuhan khusus seperti anak tuna rungu. Menurut Sayuti (2010), kebersihan mulut sangat ditentukan oleh perilaku. Perilaku orang tua sangat penting dalam terbentuknya perilaku yang mendukung atau tidak mendukung anak dalam menjaga kebersihan gigi dan mulut. Tindakan orang tua dengan memperkenalkan tindakan untuk menjaga kebersihan gigi dan mulut secara berkelanjutan dalam jangka waktu lama seperti mengajarkan tindakan kebiasaan menyikat gigi setelah makan dan sebelum tidur. Setelah itu orang tua lah yang berperan dalam mengatur dan mengawasi sehingga kesehatan rongga mulut dapat terjaga. 
Pada hasil penelitian tingkat pengetahuan responden terhadap kebersihan gigi dan mulut pada anak tuna rungu disimpulkan bahwa hanya sebagian kecil responden $(20,6 \%)$ yang memiliki pengetahuan yang tinggi, hal tersebut juga disebabkan karena faktor pendidikan. Pada hasil penelitian diperoleh pendidikan orang tua paling banyak adalah SMA yaitu $76,5 \%$, dengan pendidikan yang mereka miliki sehingga membatasi keinginan untuk meningkatkan pengetahuan mereka tentang kebersihan gigi dan mulut pada anak tuna rungu. Hai ini sesuai dengan yang diungkapkan oleh Sariningrum (2009) bahwa tingkat pendidikan merepresentasikan tingkat kemampuan seseorang dalam memperoleh dan memahami informasi kesehatan. Semakin tinggi tingkat pendidikan seseorang kemungkinan akan semakin tinggi memiliki pengetahuan mengenai kebersihan gigi dan mulut. Menurut teori yang disampaikan oleh Notoatmodjo (2010), menyatakan bahwa tingkat pendidikan mempengaruhi kesadaran akan pentingnya arti kesehatan baik pada diri sendiri maupun pada lingkungan yang mendorong kebutuhan akan pelayanan kesehatan, termasuk dalam hal ini adalah kebersihan gigi dan mulut pada anak tuna rungu.
Berdasarkan hasil penelitian status OHI-S anak tuna rungu dikategorikan dalam 2 kategori yaitu kurang baik dan baik. Lebih dari separuh (73,5\%) anak tuna rungu memiliki status kebersihan gigi dan mulut kurang baik dan hanya $(26,5 \%)$ dalam kategori baik. Hal ini sejalan dengan penelitian yang dilakukan Nurisa (2012) bahwa status kebersihan gigi dan mulut pada anak tuna rungu buruk disebabkan karena keterbatasan kemampuan dalam menjaga kebersihan gigi dan mulut.

Status kebersihan gigi dan mulut dalam kategori kurang baik banyak terdapat pada umur 9 tahun yaitu sekitar 15 anak, oleh karena itu diperlukan edukasi untuk menjaga kebersihan mulut sejak dini sehingga ketika mencapai usia dewasa kebersihan gigi dan mulut tidak terganggu.

Berdasarkan hasil penelitian tentang hubungan tingkat pengetahuan orang tua dengan kebersihan gigi dan mulut pada anak tuna rungu usia 9-12 tahun di SLB Kota Padang diperoleh hasil hasil status kebersihan gigi dan mulut kurang baik pada tingkat pengetahuan orang tua rendah $(91,7 \%)$ dibandingkan pada tingkat pengetahuan yang sedang $(66,7 \%)$ dan tinggi $(57,1 \%)$. Hasil uji statistik (chi square) diperoleh nilai $\mathrm{p}=$ $0,187>0,05$, maka dapat disimpulkan 
bahwa tidak terdapat hubungan yang bermakna antara tingkat pengetahuan orang tua dengan kebersihan gigi dan mulut pada anak tuna rungu usia 9-12 tahun di SLB Kota Padang.

Analisa peneliti terhadap hasil penelitian, tidak terdapat hubungan yang signifikan antara tingkat pengetahan orang tua terhadap kebersihan gigi dan mulut pada anak tuna rungu, akan tetapi pada hasil penelitan mengenai status kebersihan gigi dan mulut kurang baik lebih banyak pada tingkat pengetahuan orang tua yang rendah dibandingkan dengan tingkat pengetahuan orang tua yang tinggi.

Tidak signifikannya hubungan tingkat pengetahuan orang tua dengan status kebersihan gigi dan mulut pada anak tuna rungu usia 9-12 tahun, hal ini mungkin disebabkan oleh faktor lain diluar penelitian seperti adanya faktor ayah yang menjadi responden. Menurut penelitian yang dilakukan oleh Margaret (2011), didapatkan ayah masih kurang berperan dalam menjaga kebersihan gigi dan mulut anak seperti mengajari anak menyikat gigi, memberitahukan waktu menyikat gigi, serta membawa anak ke dokter gigi. Hal ini terjadi karena ibu mempunyai peran dominan dalam menjaga kebersihan gigi dan mulut anak. Ibu berperan sebagai motivator, edukator dan fasilitator. Perilaku dan kebiasaan ibu yang dicontoh oleh anak. Penelitian yang dilakukan Holt RD, dkk (2009) mengatakan bahwa sebanyak 69\% anak yang diberikan pendidikan gigi oleh ibu nya dirumah memiliki status kebersihan gigi yang baik.

Selain itu tidak signifikannya hubungan tingkat pengetahuan orang tua dengan status kebersihan gigi dan mulut pada anak tuna rungu usia 9-12 tahun juga dipengaruhi oleh faktor penguat (reinforcing faktor) antara lain faktor sikap dan perilaku tokoh masyarakat, tokoh agama dan petugas kesehatan.

Pada penelitian ini terdapat keterbatasan yang ditemukan selama penelitian berlangsung, yaitu kurangnya sampel dan lamanya waktu penelitian. Selain itu orang tua dari murid SLB yang dijadikan subyek penelitian ada yang tidak hadir pada hari penelitian berlangsung sehingga kuisioner diisi di rumah.

\section{KESIMPULAN}

Berdasarkan hasil penelitian tentang “ hubungan tingkat pengetahuan orang tua dengan status kebersihan gigi dan mulut pada anak tuna rungu usia 9 12 tahun di SLB Kota Padang ”, maka dapat disimpulkan bahwa :

1. Lebih dari separuh anak memiliki kebersihan gigi dan mulut pada kategori kurang baik. 
2. Hanya sebagian kecil orang tua memiliki tingkat pengetahuan tinggi.

3. Tidak terdapat hubungan yang bermakna antara tingkat pengetahuan orang tua dengan status kebersihan gigi dan mulut $(\mathrm{OHI}-\mathrm{S})$ anak tuna rungu. Pvalue= 0,187 .

\section{KEPUSTAKAAN}

1. Basuni, Cholil, Deby Kania Tri Putri. Gambaran Indeks Kebersihan Mulut Berdasarkan Tingkat Pendidikan Masyarakat Di Desa Guntung Ujung Kabupaten Banjar. Dentin (Jur. Ked. Gigi), Vol II. No 1. Maret 2014 : $18-23$.

2. Budhiarto, 2008. Ilmu Perilaku Kesehatan dan Pendidikan Kesehatan Gigi. Jakarta : EGC.

3. Christy Mintjelungan, Kustina Zuliari, Elvira Yesiska. 2011. Gambaran Status Periodontal dan Kebutuhan Perawatan Anak Tunarungu Usia Sekolah di Sekolah Luar Biasa GMIM Damai Tomohon. http://download.portalgaruda.org/

4. Dalimunthe, Saidina Hamzah. 2006. TerapiPeriodontal. Medan: Departemen Periodonsia Fakultas Kedokteran Gigi $\underline{\text { Sumatera Utara }}$

5. Dalimunthe, Saidina Hamzah. 2008. Periodonsia. Departemen Periodonsia Fakultas Kedokteran Gigi Universitas Sumatera Utara. Edisi revisi. Medan.

6. Damafitra, Lita. 2015. Efektifitas Video dan Bahasa Isyarat Sebagai Media Penyuluhan Kesehatan Gigi dan Mulut pada Anak Penderita TunaRungu. http://repository.unej.ac.id/

7. Data Dinas Pendidikan Kota Padang. 2014.

8. Data Kementrian Kesehatan. 2010.

21.
9. Data Sensus Nasional Biro Statistik (BPS). 2007.

10. Monica M. Sengkey, Damajanty H.C. Pangemanan, Christy N. Mintjelungan. Status Kebersihan Gigi dan Mulut Pada Anak Autis di Kota Manado. Jurnal e- Gigi ( eG), Volume 3, Nomor 2, Juli-Desember 2015.

11. Kaban, Moslehzadeh. Oral Hygiene Index ( Greene and Vermilion,1960). Diperoleh 5 Desember 2015. http://www.mah.se/CAPP/Methods-andIndices/Oral-Hygiene-Indiced.

12. Notoadmojo, Soekidjo. 2003. Ilmu Kesehatan Masyarakat (prinsip-prinsip dasar). Jakarta : Rineka Cipta

13. John G. Greene, Jack R.Vermillion. 1964. The Simplified Oral Hygiene Index- The Journal of the American Dental. http:// jada.ada.org/ article/

14. Putri, Meganda Hiranya;Herijulianti, Eliza;Nurjannah, Neneng. 2010.

Pencegahan Penyakit Jaringan Keras dan Jaringan Pendukung Gigi. Jakarta : EGC

15. Pusat Data dan Informasi Kementrian Kesehatan RI. Penyandang Disabilitas pada Anak. 2014.

16. PIH Unair. 2012. Sehat Gigi dan Mulut Anak Berkebutuhan Khusus. http://www.unair.ac.id/sehat-gigi-danmulut-anak-berkebutuhan-khusus...

17. Prijantojo. 1996. Kondisi Jringan Periodonsium pada Kelompok Masyarakat dengan Perbedaan Frekuensi Penyikatan Gigi. Jakarta: EGC

18. Riskesdas SKRT, Departemen Kesehatan RI, 2007.

19. http://terbitan.litbang.depkes.go.id/penerbit an/index.php/blp/catalog/download.pdf.

20. Susi, Hafni Bachtiar, Ummul Azmi. Hubungan Status Sosial Ekonomi Orang Tua dengan Karies pada Gigi Sulung Anak Umur 4 dan 5 Tahun. Majalah Kedokteran Andalas No.1. Vol.36. Januari-Juni 2012. 